\title{
The Use of 3D-printing Technology in Rhinoplasty: Change Horizons, Change Principles, Change Future
}

\author{
Seied Omid Keyhan ${ }^{1-4}$ and Mohammad Hosein Amirzade-Iranaq ${ }^{5-7 *}$ \\ ${ }^{1}$ Assistant Professor, Department of Oral \& Maxillofacial Surgery, Faculty of Dentistry, Birjand University of Medical Science, Iran \\ ${ }^{2}$ Vice Presidential Organization of Technology of the Islamic republic of Iran \\ ${ }^{3}$ Stem cell \& Regenerative Medicine Network, Shahid Beheshti University of Medical Sciences, Iran \\ ${ }^{4}$ Cranio Maxillofacial Research Center, Tehran Dental Branch, Islamic Azad University, Iran \\ ${ }^{5}$ Student Research Committee, Shahid Sadoughi University of Medical Sciences, Iran \\ ${ }^{6}$ Universal Network of Interdisciplinary Research in Oral and Maxillofacial Surgery (UNIROMS), Universal Scientific Education and Research Network \\ (USERN), Iran
}

${ }^{7}$ International Otorhinolaryngology Research Association (IORA), Universal Scientific Education and Research Network (USERN), Iran

Submission: September 27, 2017; Published: October 04, 2017

*Corresponding author: Mohammad Hosein Amirzade-Iranaq, Student Research Committee, Shahid Sadoughi University of Medical Sciences; Universal Network of Interdisciplinary Research in Oral and Maxillofacial Surgery (UNIROMS), Universal Scientific Education and Research Network (USERN); International Otorhinolaryngology Research Association (IORA), Universal Scientific Education and Research Network (USERN), Iran, Tel: +98 913 2252603; Email: h.amirzade@gmail.com

\section{Letter to Editor}

Rhinoplasty surgery include reshaping, rearranging and sometimes reconstructing -due to trauma, malignancies and etc.variety of tissues such as skin, cartilage and bone to reach ultimate goal of cosmetic surgery which is to provide aesthetic along with function similar to normal organ. Advantages of techniques and also biomaterials help clinician for reach to this goal. In contrast, there are still limitations, which may resolve through new advanced technologies [1,2].

For the first time Langer and Vacanti introduced the definition of tissue engineering [3], this approach explain the basics of functional substitutes for tissue damaging and how to reconstruct and regenerate theses tissue based on principles of biology and medical engineering. This new field in contrast to the former biomaterial thoughts, presents incredible disciplines which diverse the goal of regeneration induction of traumatized or damaged tissue rather than substitution with inert parts [4]. The architecture of normal extracellular matrices can be simulated at the nano scale level with use of scaffolds. This provides the primary base for the regeneration of new tissue [5]. Originally a "top-down" approach was used as a tissue engineering method for scaffold generation. In this method, cells are seeded onto a biodegradable and biocompatible scaffold, and are predicted to migrate and fill the scaffold hence creating their own matrix.

\section{Methodology}

Through years, three-dimensional (3D) printing has been used to produce variety of products for different applications.
Three-dimensional (3D) printing is a manufacturing method in which objects are made by fusing or depositing materials such as plastic, metal, ceramics, powders, liquids, or even living cells in layers to produce a 3D object. This technology describes a process by which a product derived from a computer-aided design (CAD) is built in a layer-by-layer fashion. After 1986, this process began to gain momentum and received appreciation worldwide and held importance in different fields, including the medical field. 3D printing is becoming a subject of great interest in surgery in the last decade.

Three-dimensional printing provides ability to generate scaffolds precisely with higher flexibility which depends on the type of materials used to make such scaffolds. Three-dimensional printing uses an additive manufacturing process where a structure is fabricated using a layer-by-layer process. Materials deposited for the formation of the scaffold may be cross-linked or polymerized through heat, ultraviolet light, or binder solutions. 3D printed scaffolds can be prepared, optimized and enhanced for tissue engineering with aid of this technology [6].

The 3D printing generated scaffolds are structures with controlled pore size and interconnectivity which is a critical factor to provide the ability of scaffold to support cell growth and tissue formation. For 3D printing there is a need to Computer Assisted Design (CAD). Designed model printed and then it depends to each 3D printing system to "print" the desired scaffold structure. Various researches aimed to use these 3D printed scaffolds to reconstruct tissues for rhinoplasty. The main goal of almost all of these 
researches is to reach clinically significant results to regenerate nasal bone for dorsal augmentation [7].

Due to bio-mechanical limitations and difficulties in diffusion properties of these scaffolds, the "top-down" technique faces several challenges. To resolve, "bottom-up" methods have been developed including cell-encapsulation with micro scale hydro gels, cell aggregation by self-assembly, generation of cell sheets, and direct printing of cells. Various methods such as micro fluidics, magnetic fields [8], acoustic fields [9], and surface tension [10] introduced to assemble these complex tissue units.

Researchers created a few methods of printing with the goal of finding a solution to the given problems for optimal tissue biofabrication. Thermal Inkjet bio-printing with bio-ink, and directwrite bio-printing both make use of modified inkjet printers but with varied application techniques. Organ printing with tissue spheroids is the recent achievement of researches which seems promising to fabricate tissues directly.

\section{Discussion}

Organ printing offers a pathway to generate a scalable and reproducible of tissue-engineered products in large amounts. On the other hand, another advantage of the method is to allow the precise3D positioning of several cell types, simultaneously. This causes ability to create tissues with a high level of cell density. This may be promising to avoid complications of various types of grafts for dorsal augmentation and to reach the ultimate goal of cosmetic procedure. Financial difficulties are the major limitation to develop a natural-like, fully functioning fabricated human tissue [11].

\section{Conclusion}

This challenge must definitely be overcome if bio-fabrication technology is to allow the creation of a functional living human organ. In the meantime, effective and positive interaction of the integrated and well-established fundamentals of biology along with engineering concepts is the key to realize the true potential of this exciting area.

\section{References}

1. Keyhan SO, Hemmat S, Mehriar P, Khojasteh A, Asayesh MA (2015) Advanced Adjunct Orthosurgical Esthetic Procedures. In: A Textbook of Advanced Oral and Maxillofacial Surgery 2.

2. Amirzade-Iranaq MH, Masoumi SMR (2017) 174: Etiology And Patterns Of Facial Fractures In Iran: A Systematic Review And MetaAnalysis. BMJ 7(Suppl 1): bmjopen-2016-015415.174.

3. Lanza R, Langer R, Vacanti JP (2011) Principles of tissue engineering: Academic press.

4. Fisher MB, Mauck RL (2013) Tissue engineering and regenerative medicine: recent innovations and the transition to translation. Tissue Engineering Part B: Reviews 19(1): 1-13.

5. Wei G, Ma PX (2008) Nanostructured biomaterials for regeneration. Advanced functional materials 18(22): 3568-3582.

6. Do A-V, Khorsand B, Geary SM, Salem AK (2015) 3D Printing of Scaffolds for Tissue Regeneration Applications. Advanced Healthcare Materials 4(12): 1742-1762.

7. Keyhan SO, Ghanean S, Navabazam A, Khojasteh A, Amirzade-Iranaq MH (2016) Three-Dimensional Printing: A Novel Technology for Use in Oral and Maxillofacial Operations. In: A Textbook of Advanced Oral and Maxillofacial Surgery: InTech.

8. Xu F, Wu CaM, Rengarajan V, Finley TD, Keles HO, et al. (2011) Threedimensional magnetic assembly of microscale hydrogels. Advanced Materials 23(37): 4254-4260.

9. Xu F, Finley TD, Turkaydin M, Sung Y, Gurkan UA, et al. (2011) The assembly of cell-encapsulating microscale hydrogels using acoustic waves. Biomaterials 32(31): 7847-7855.

10. Kachouie NN, Du Y, Bae H, Khabiry M, Ahari AF, et al. (2010) Directed assembly of cell-laden hydrogels for engineering functional tissues. Organogenesis 6(4): 234-244.

11. Cui X, Boland T, D D'Lima D, K Lotz M (2012) Thermal inkjet printing in tissue engineering and regenerative medicine. Recent patents on drug delivery \& formulation 6(2):149-155.

\section{Your next submission with Juniper Publishers will reach you the below assets}

- Quality Editorial service

- Swift Peer Review

- Reprints availability

- E-prints Service

- Manuscript Podcast for convenient understanding

- Global attainment for your research

- Manuscript accessibility in different formats ( Pdf, E-pub, Full Text, Audio)

- Unceasing customer service

Track the below URL for one-step submission https://juniperpublishers.com/online-submission.php 